\title{
REGIONÁLNE DISPARITY NA SLOVENSKU VO SVETLE SOCIOEKONOMICKÝCH UKAZOVATEŌOV
}

\section{REGIONAL DISPARITIES OF SLOVAKIA BASED ON SOCIOECONOMIC INDICATORS}

\section{RNDR. Slavomír BUCHER, PHD.}

\author{
Katedra geografie a aplikovanej geoinformatiky $\mid$ Depar.t of Geography and Applied Geoinformatics \\ Fakulta humanitných a prírodných vied Faculty of Humanities and Natural Sciences \\ Preǵovská univerzita v Preg்ve University of Presov \\ $\bowtie$ Studentská Ul. 17. Novembra 1, 08116 Preg்v, Slovak Republic
}

E-mail: slavobucher@yahoo.com

\begin{abstract}
Anotácia
V príspevku sa venujeme hodnotením vývoja vybraných socioekonomických ukazovateŎvv na území Slovenska v období rokov 2007 ï 2013. Medzi socioekonomické indikátory regionálnych nerovností, ktoré sa snağ́me v nag்om llánku analyzovaš patria ï miera evidovanej nezamestnanosti, miera evidovanej nezamestnanosti ğ́en, priemerná mesa! ná mzda, pol et uchádzal ov o zamestnanie na 1000 ekonomicky aktívnych obyvateひ̆v a pol et dlhodobo evidovaných uchádza! ov o zamestnanie na 1000 ekonomicky aktívnych obyvateひ̆v. Na vyjadrenie vývoja socioekonomických disparít sme pouğili jednoduché miery variability ï ako je varia! ný koeficient.
\end{abstract}

\section{KŎị̂vé slová}

socioekonomické ukazovatele, miera nezamestnanosti, NUTS III, regionálne disparity, varia!̣ý koeficient

\section{Annotation}

The aim of this paper is to define of selected socio-economic indicators in Slovakia during the period 2007 ï 2013. Contribution focuses on changes of socio-economic indicators like unemployment rate, unemployment rate of women population, average gross nominal wage, number of disposable job applicants (graduates) per 1.000 economically active population and number of long-term unemployment applicants per 1.000 economically active population. To express of the development of socio-economic disparities, we used a simple measure of variability ï such as coefficient of variation.

Key words

socio-economic indicators, unemployment rate, NUTS III, regional disparities, the coefficient of variation

JEL classification: $R 120$, R110

\section{Úvod}

K významným problémom súl asnej Európy patrí nezamestnanosS̆ ktorá je spojená s nerovnomerným rozloǵením produkl ných síl a hospodárskou krízou. S rastom nezamestnanosti dochádza aj k sociálnemu vylúl eniu, chudobe a degradácii kvality ǵivota jedinca, prípadne skupiny osôb (Angelovil, 2012).

Rast nezamestnanosti závisí od fázy ekonomického cyklu, ale zároveŔ je ovplyvnený nedostatol nou ponukou a dopytom medzi ġkolským systémom a trhom práce, demografickými, sociálnymi, psychologickými !̣initeŎni. Na Slovensku sa od nástupu krízy nedarí efektívne zmierŔovaŠ dopady nezamestnanosti nakoQ̆ko sú nedostatol ne vyuğ́vané nástroje aktívnej politiky gátu, ! o má za 
následok prehథ̄enie regionálnych rozdielov socioekonomického rozvoja regiónov. Rozdielna úroveŔ nezamestnanosti v jednotlivých regiónoch Slovenska má diferencovaný dosah na kvalitu ǵvvota, s ktorou sú spojené psychologické riziká dlhodobej nezamestnanosti, sociálna izolácia a pokles ğivotnej úrovne obyvateQ̆tva.

V práci hodnotíme skupinu vybraných socioekonomických ukazovateQ̆v, medzi ktoré zaraṆujeme aj nezamestnanosŠ Socioekonomické ukazovatele a najmä ich kvantitatívne vyjadrenia prostredníctvom ġatistiky sledovaných hodnôt pribliǵujú sociálnu situáciu obyvateQ̆tva sledovaných priestorových jednotiek (obec, okres, kraj a pod.) a naznal ujú trendy jej vývoja (Michaeli, Matlovil, Iğok a kol., 2010).

Problematika socioekonomickej vyspelosti regiónov je úzko spätá s nastavením a hodnotením nástrojov regionálnej politiky. Spôsob, akým je táto tematika ponímaná determinuje proces regionálnej analýzy a teda aj jej výsledky, ktoré sú kđ̣̆i ové pre regionálnu politiku (Horká, 2013).

K problematike regionálnej konkurencieschopnosti, regionálnym disparitám prispeli autori ako Wokoun (2010), Huggins (2003), Skokan (2004), Turok (2003) a Angelovi! (2009).

\section{CieOa metodika práce}

CieC̆m tohto !̣ lánku je zhodnotiŠ a identifikovaŠ prị́ iny nezamestnanosti v samosprávnych krajoch na Slovensku podQ̆ vybraných faktorov, ktoré sa na jej tvorbe podieăjú. Vplyvom pôsobenia krízy sa regionálne rozdiely v nezamestnanosti eg̉e viac prehథ̄ili. ÚroveŔ nezamestnanosti je výrazne podmienená ekonomickými, demografickými a sociálnymi !̣initeŏni. Snahou tejto analýzy bliğğe ğpecifikovaŠ vybrané ukazovatele, ktoré svojou povahou pôsobia na kvalitu ğivota a ǵivotnú úroveŔ obyvateQ̆v v jednotlivých regiónoch.

Vzhădom k uvedeným skutoḷ nostiam sme si zvolili pre nag̉ı analýzu nasledovný súbor ukazovateQ̆v, ktoré výraznou mierou ovplyvŔujú ekonomické a sociálne podmienky a konkurencieschopnosŠslovenských regiónov:

- Miera nezamestnanosti ï reprezentuje základný ekonomický indikátor, ktorý názorne zobrazuje aktuálnu ekonomickú situáciu v regióne z dôvodu intenzity s akou reaguje na zmeny v ekonomike

- Miera nezamestnanosti ğen ï reprezentuje gender kategóriu, ǵeny sú vg̉eobecne vnímané na trhu práce ako rizikový faktor pri hădaní zamestnania (tehotenstvo, výchova detí) v porovnaní s muǵmi. Predpokladáme, ǵe aj vplyvom krízy sa rozdiely medzi pohlaviami v miere nezamestnanosti budú líğšv neprospech neǵného pohlavia

- Priemerná mesa!̣á mzda ï primárny ukazovateŎ sociálnej úrovne regiónu reflektujúci disponibilné zdroje pre uspokojovanie základných ǵivotných potrieb a zaobstaranie spotrebite@̆kých ğandardov

- Poḷ et uchádza!̣ov (absolventov) o zamestnanie na 1000 ekonomicky aktívnych obyvate $\mathbf{o} v$ ï významný ukazovateŎ pojednávajúci o prepojenosti ġkolstva na trh práce. Vplyvom krízy sa výrazne prehlbuje z dôvodu pretrvávajúcej vysokej diferencovanosti poǵiiadavkami trhu a ponukou zrul ností a schopností absolventov g̉ôl

- Poḷet dlhodobo evidovaných uchádza!̣ov o zamestnanie na 1000 ekonomicky aktívnych obyvate Öv ï Jedná sa o uchádzaḷ ov, ktorí sú v evidencii ÚPSVaR SR viac ako 12 mesiacov. Dlhodobo nezamestnané osoby strácajú návyky, nemôǵ sa adaptovaŠ na nové technológie a podmienky trhu práce. Dlhodobá nezamestnanosŠ prispieva k sociálnemu vylúl eniu a zvýğenej kriminalite

CieC̆m práce je taktieǵ poukázaŠ na priestorovú polarizáciu krajov komparáciou vybraných ukazovateQ̆v, zberom sekundárnych informácií v jednotlivých regiónoch na Slovensku. Jednotlivé údaje sme spracovali za ! asový horizont 2007- 2013 z databáz Slovenského ǵatistického úradu (RegData). 


\section{Hodnotenie jednotlivých indikátorov z poh âdu priestorovej analýzy dát}

VṆaka rôznorodosti prírodných podmienok a následne diferencovanému vývoju hustoty zaQ̆ıdnenia dog̉o k nerovnomernému rozloǵeniu výrobných kapacít vjednotlivých regiónoch, lo malo za následok rozdielny vývoj socioekonomických aktivít v geografickom priestore Slovenska. Významný vplyv na konkurencieschopnosŠ územia mala aj exponovanosŠ jednotlivých regiónov v okrajových horských a podhorských oblastiach, ktorá pol as masívnej industrializácie v 60. a 70. rokoch 20. storol ia znemoǵŔovala výraznejğiu urbanizáciu priestoru. Faktor juǵnej hranice ako potenciálnej konfliktnej zóny zohrával $\mathrm{v}$ !̣ asoch prvej Ḷeskoslovenskej republiky dominantnú úlohu v procese plánovania urbanizácie a industrializácie územia.

Pol as relatívne krátkeho obdobia stability v národnej ekonomike, ktoré nastalo po tzv. kríze v 90. rokoch 20. storol ia a prechode z plánovaného na trhové hospodárstvo sa Slovensko v r. 2008 opäS ocitlo pred novou výzvou v podobe globálnej hospodárskej krízy (Obr. 1).

Vývoj miery nezamestnanosti v sledovanom období 2007 ï 2013 v jednotlivých krajoch bol problémový. Charakteristickou !̣ rtou je priestorová diferenciácia miery nezamestnanosti na krajskej a okresnej úrovni, ktorá sa poḷ as krízy výraznejg̉e prehథ̄ila. Vo vg̉etkých krajoch na Slovensku pol et nezamestnaných medzirol ne stúpol. V roku 2013 najviac uchádzaḷ ov o zamestnanie a zároveŔ najvyg̈gie hodnoty miery nezamestnanosti evidujeme v Preǵbvskom $(19,4 \%)$, Banskobystrickom $(18,3$ $\%)$ a Koğckom kraji $(17,2 \%)$. Na druhej strane najniǵg̉e hodnoty zaznamenali Bratislavský $(6,2 \%)$ a Trnavský (9,2\%) kraj (ĠU SR, 2014).

Obr. 1: Miera evidovanej nezamestnanosti za jednotlivé kraje v rokoch 2007 - 2013

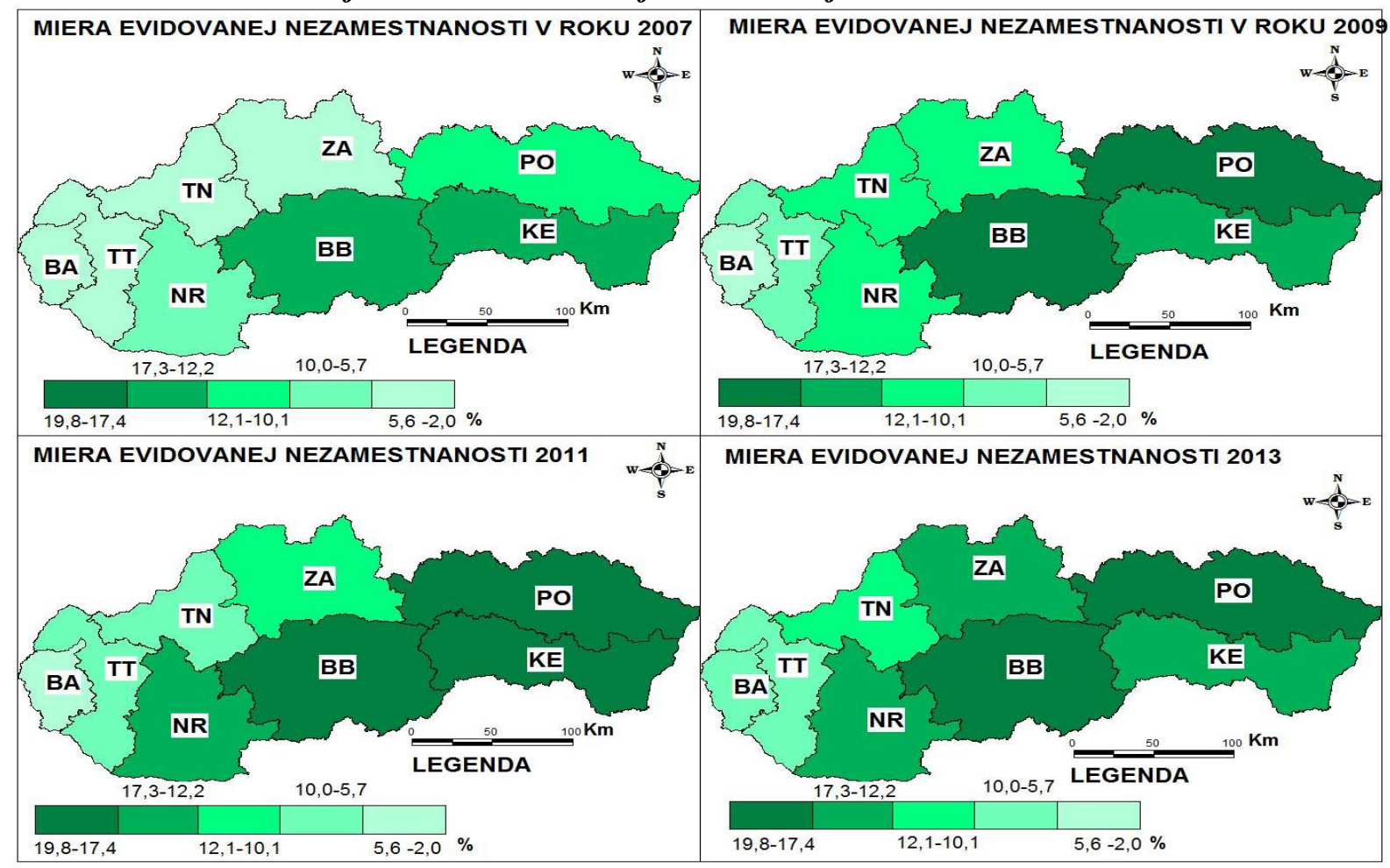

Zdroj: GÚ SR, 2014

Diverzitu miery nezamestnanosti v sledovanom období reflektuje aj varial ný koeficient, ktorý na úrovni krajov klesol v roku 2007 z 58,5 \% na 39,6 \% v roku 2012. Pokles hodnôt varial ného koeficientu symbolizuje zníǵenie medzi krajských rozdielov miery nezamestnanosti, na druhej strane jeho hodnoty výrazne vzrástli v porovnaní s predkrízovou situáciou (Graf 1). 
Graf 1: Miera evidovanej nezamestnanosti za roky 2007 a 2013 (\%)

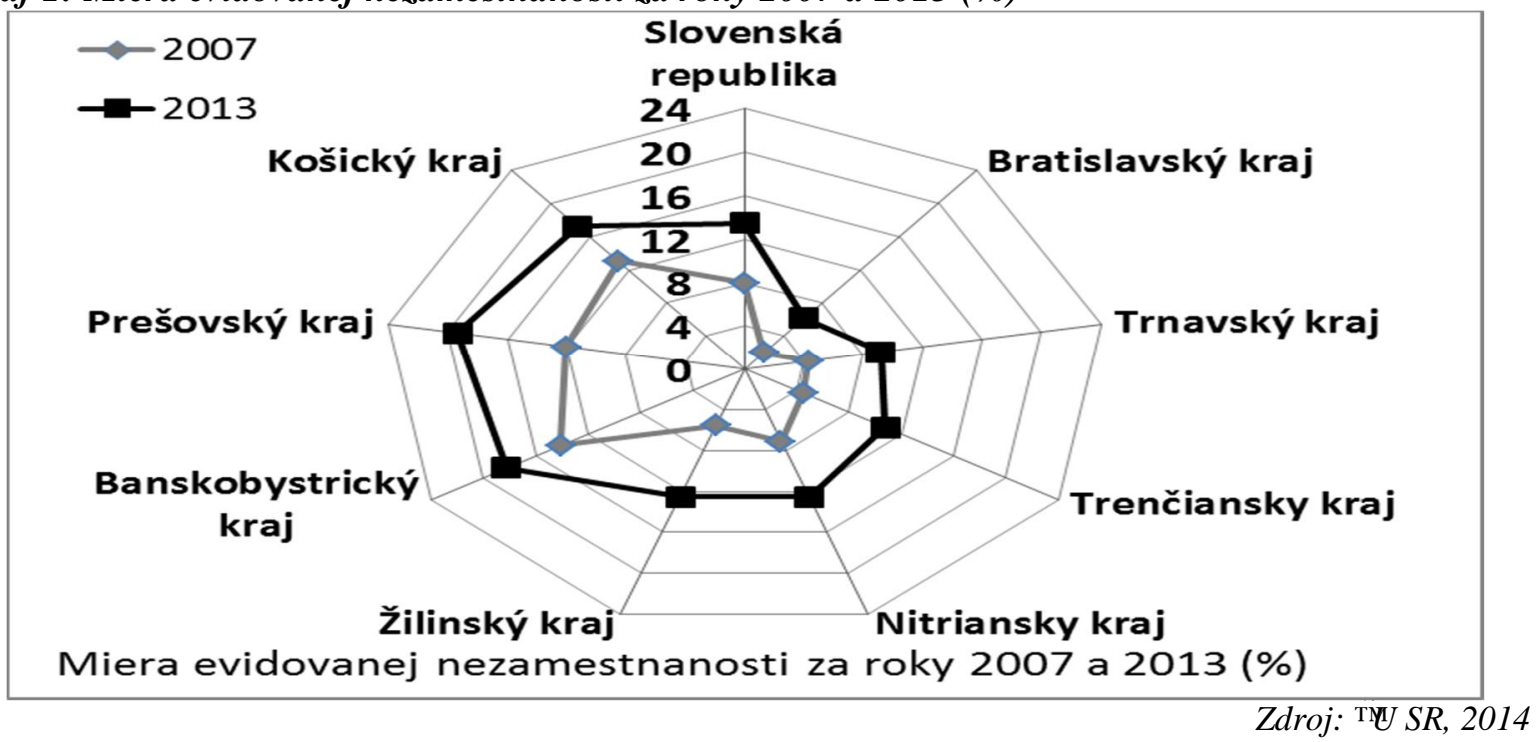

Pri komparácii mier nezamestnanosti sme $\mathrm{v}$ jednotlivých mapách pouğili rovnaké intervalové rozpätie pre roky 2007 a 2012, pril om sme vychádzali z údajov v r. 2012. Jednotlivé okresy boli následné rozdelené do piatich kategórií (Obr. 2):

A. Vyspelé regióny (podpriemerná miera nezamestnanosti):

A1: Bratislava I, Bratislava II, Bratislava III, Bratislava IV, Bratislava V, Senec, Pezinok, Galanta, Trnava, Púchov, Pieğšany, Myjava, Skalica, Malacky, Nové Mesto nad Váhom, Hlohovec. Spolu 16 okresov (2012), v roku 2007 patrilo do tejto kategórie, ktorá je vymedzená mierou nezamestnanosti meng்u ako $9,1 \%$ celkovo 49 okresov.

A2: Trenḷ̂n, Ilava, Kog̈ce IV, Martin, Banská Bystrica, G̣ilina, Kog̈ce III, Nitra, Kog̈ce II, Kog̈ce I, $\dot{G} \mathrm{a}$, Zvolen, Senica, Bánovce nad Bebravou, Poprad, Povaǵská Bystrica. Spolu 16 okresov (2012), v roku 2007 prináleǵalo tejto kategórií 9 okresov. Miera nezamestnanosti sa v tejto kategórii pohybuje v rozmedzí $9,1 \%$ aǵ $12,7 \%$.

B. Prechodné regióny, ktoré môǵı byŠ úspeg̉né (priemerné hodnoty miery nezamestnanosti): Topođ̣̆any, Dunajská Streda, Prievidza, Zlaté Moravce, Ruǵomberok, L̦adca, Liptovský Mikulág Tvrdoğn, Partizánske, Tur! ianske Teplice, Nové Zámky, Kysucké Nové Mesto, G̣iar nad Hronom, Dolný Kubín, Levice. Celkovo patrí do tejto kategórie 15 okresov, v roku 2007 ich bolo 10. Miera nezamestnanosti je v intervale $12,7 \%$ aǵ $15,8 \%$.

\section{Depresné regióny (podpriemerné hodnoty miery nezamestnanosti):}

C1: Byt|̣a, Stará ŌubovŔa, Námestovo, Banská Ġiavnica, Humenné, Preg̉ov, Spiğkká Nová Ves, Komárno, Brezno, Detva, Michalovce, Snina, Krupina, Stropkov, Garnovica, Levol a. Spolu 16 okresov, v roku 2007 ich bolo 9. Miera nezamestnanosti osciluje od 15,8 \% do 21,7\%.

C2: Medzilaborce, Bardejov, Svidník, Vranov nad TopQ̆u, Gelnica, Kog̉ce-okolie, Lul enec, Veăxý Krtíg Sobrance, Trebig̉ov, Poltár, Sabinov, RoǵŔava, Keǵmarok, Revúca a Rimavská Sobota. V tejto kategórii je spolu 16 okresov s najvyğğu mierou nezamestnanosti, ktorá je v rozmedzí od 21,7 \% do 35,6\%. V roku 2007 sa v tejto kategórii umiestnili dva okresy (Rimavská Sobota a Revúca). 


\section{Obr. 2: Miera evidovanej nezamestnanosti v okresoch Slovenska 2007 a 2012}
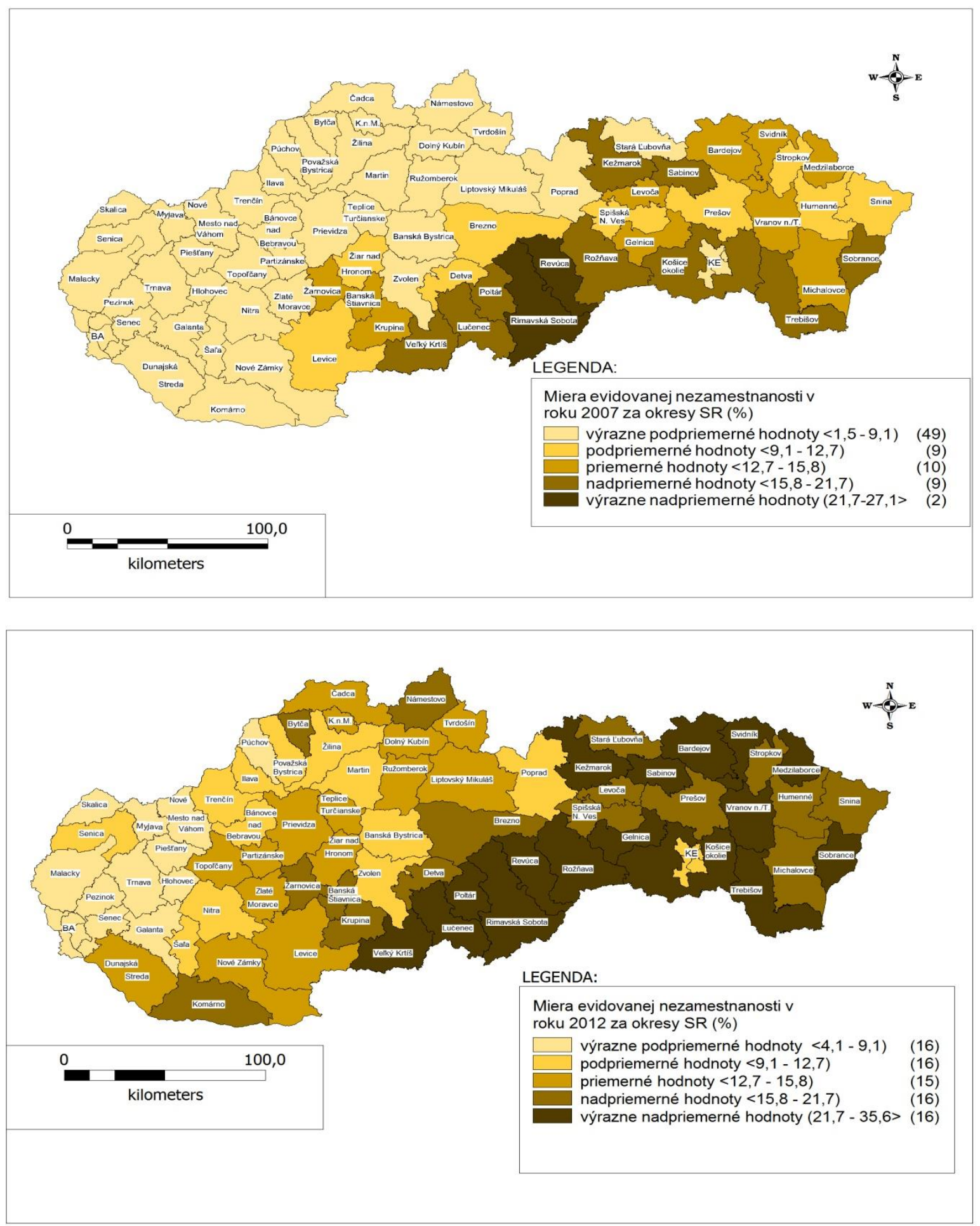

Zdroj: GU SR, 2014

Autori ako Korec (2003), Hampl (2001) vo svojich prácach upriamujú pozornosŠ na tzv. fenomén západno-východného gradientu, ktorý v znal enej miere determinuje makropolohu krajín V4. Regióny lokalizované v blízkosti hraníc s Rakúskom a Nemeckom, l o je prípad aj Bratislavského kraja (spoloḷ ná hranica s Rakúskom) majú lepg̉e podmienky pre svoj socioekonomický vývoj. Najmä poḷ as transformal ného obdobia sa tieto regióny dokázali plynulejg̉e adaptovaŠna nové trendy a inovácie vo výrobno-odvetvovej ğruktúre svojho hospodárstva, ! o im umoǵnilo prílev priamych zahranil ných investícií. 
Nemenej dôleğitý vplyv na výyoj nezamestnanosti a socioekonomického progresu regiónov mala aj regionalizácia Slovenska podă Lukniğa (1985) na Západoslovenský centralizaḷ ný región (ZCR) a Východoslovenský centralizal ný región (VCR). Tieto územia predstavujú aj v súl asnosti jadrové regióny, z ktorých sa inovácie ğria do susedných regiónov. Práve regióny s najniğǵou mierou nezamestnanosti sú lokalizované v západoslovenskom centralizal nom regiónu. Okresy v tomto regióne vN̦aka diverzifikovanej hospodárskej ğruktúre vyuǵili svoje komparatívne výhody, ktoré prispeli $\mathrm{k}$ tvorbe nových pracovných príleğitostí a rozvoju podnikateQ̆kého prostredia. Geografická blízkosŠ Viedne a Brna napomohla regiónu prilákaŠzahranil ných investorov. Ekonomické impulzy sa z tohto regiónu ğrili aj na Povaǵie, ktoré predstavuje ekonomicky, sídelne a komunikal ne najcennejg̈e územie severozápadného Slovenska. Tento priestor tzv. Západoslovenský centralizal ný región (ZSR) tvorí spojnicu medzi jadrovými územiami Koğc a Bratislavy.

Kritické miery nezamestnanosti vykazujú dva regióny ï severovýchod Slovenska a juh stredného Slovenska. Tieto územia majú vysoký podiel vidieckeho obyvateătva pril om centrálne mesto okresu sa stáva hlavným zdrojom pracovných príleǵitostí a periférne oblasti vykazujú Joraz väl gie marginality spojené s nepriaznivým demografickým vývojom a ġruktúrou obyvateQ̆tva (vysoký podiel rómskeho obyvateQ̆tva, nízky stupeŔ dosiahnutého vzdelania), nedostatol ná infrağruktúra, ktorá bráni dochádzke do zamestnania.

Uplatnenie Q̆dí na trhu práce je podmienené rôznymi charakteristikami, ako napr. pohlavie, vek, vzdelanie, prísluğos Š k etnickej skupine. Nasledujúci ukazovateŎ definuje mieru nezamestnanosti ğien v jednotlivých krajoch SR za obdobie 2007 ï 2013. G̦eny sú vǵeobecne vnímané na trhu práce ako skupina vystavená riziku opakovanej nezamestnaností, pril om ekonomické a sociálne rozdiely medzi samosprávnymi krajmi tento negatívny fenomén eg̉e viac prehlbujú.

Bratislavský kraj dlhodobo vykazuje najniğğu mieru nezamestnanosti ğien (Graf 2), ! o je významne ovplyvnené najmä jeho ekonomickou výkonnosŠou výrazne presahujúcou priemer Slovenska. Priemerná miera nezamestnanosti ǵien za obdobie 207 ï 2013 bola na Slovensku 12,7 \%. Najniǵğe priemerné hodnoty miery nezamestnanosti ǵien dosahoval Bratislavský $(4,5 \%)$ a Trnavský kraj $(8,5$ $\%$, najvyğgie hodnoty kopírujú kraje, kde je aj najvyğga celková miera nezamestnanosti ï Banskobystrický $(18,9 \%)$, Preg̉ovský $(18,3 \%)$ a Koğcký kraj $(17,4 \%)$. V sledovanom období medziroḷ ne miera evidovanej nezamestnanosti vzrástla vo vǵetkých krajoch. Mierny pokles evidovanej miery nezamestnanosti ǵien pozorujeme pri porovnaní rokov 2012 a 2013 vo vg̈etkých krajoch okrem Bratislavského kraja (Trnavský kraj z 10,48 \% na 10,36 \%, Trenl iansky kraj z 11,98 \% na $11,96 \%$, Nitriansky kraj zo $16,09 \%$ na $14,65 \%$, G̣ilinský kraj zo $14,34 \%$ na 13,62 \%, Banskobystrický kraj z 21,2 \% na 18,68 \%, Preǵovský kraj z 21,08 \% na 20,31 \% a Kog̉cký kraj z $20,28 \%$ na $18,66 \%)$.

Hodnoty miery nezamestnanosti ǵien v jednotlivých krajoch kopírujú ich exponovanosŠ v rámci Slovenska, klasifikáciu typov ekonomických ! inností ako aj dôsledky ekonomickej recesie.

Vyğğa nezamestnanosŠğien spoḷ íva v ich uplatnení na trhu práce, keṆǵe pol as kariéry a najmä v jej zal iatkoch musia preruğs šacovný pomer z dôvodu materských povinností. Rodinné povinnosti veQ̆krát znemoǵŔujú ǵenám investovaŠ l as a peniaze do budovania svojej kariéry, l o sa odzrkadQ̆jje niơğm príjmom a obmedzeným pracovným postupom. G̦eny vo väl ğej miere pristúpia na ḷiastkový pracovný úväzok, z dôvodu niğg̉eho dosiahnutého vzdelania alebo rodinných povinností. Vyğgej miere nezamestnanosti ğien bráni aj nepriaznivá ğruktúra ponuky práce na nag̉om pracovnom trhu, keṆǵe je dopyt po robotníckych a remeselníckych pozíciách, na druhej strane klesá ponuka administratívnych pozícií, kde je zamestnaných najviac ğien. 
Graf 2: Miera evidovanej nezamestnanosti ǵen za roky 2007 a 2013 (\%)

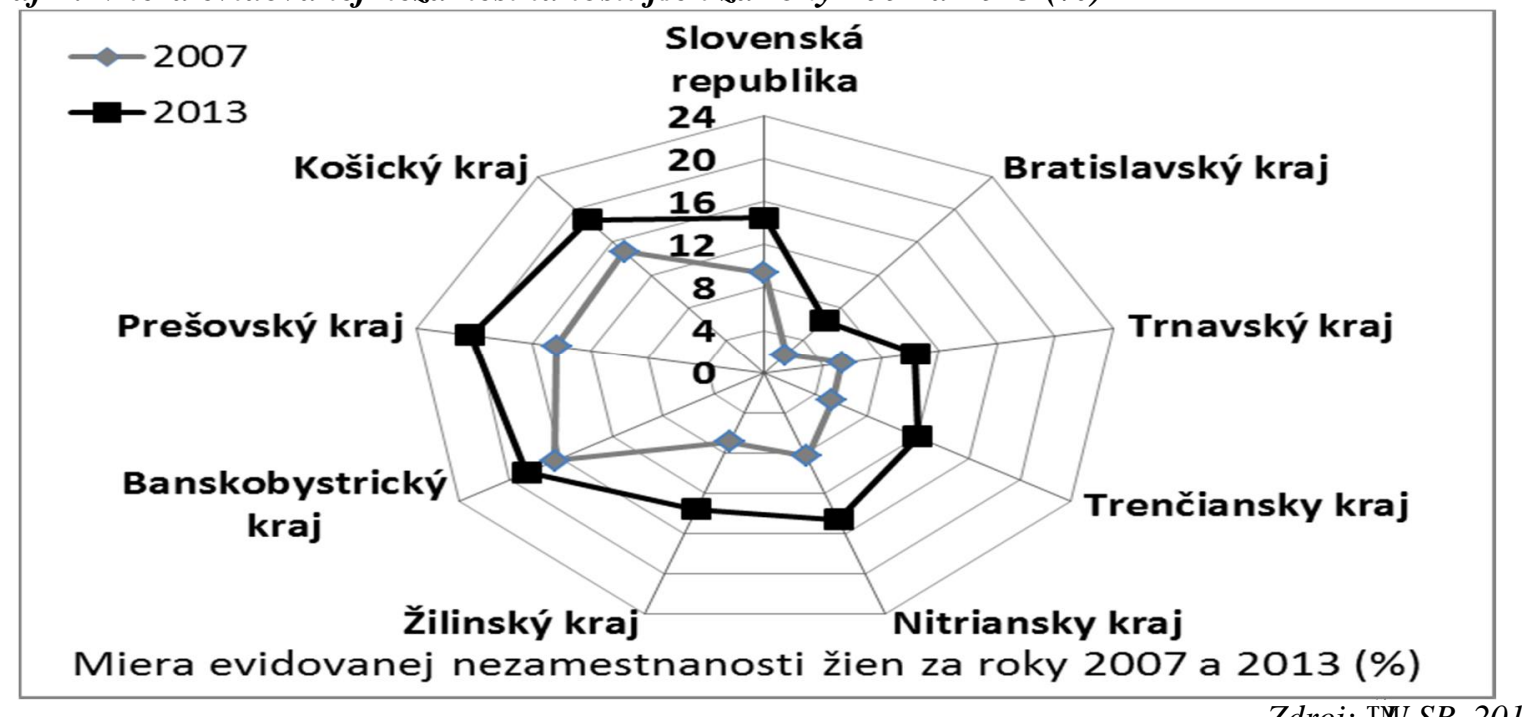

Zdroj: GU SR, 2014

DiferencovanosŠpriemernej mesal nej mzdy v samosprávnych krajoch Slovenska má priamy dopad na zamestnanosŠ Priemerná mesal ná mzda v roku 2012 dosahovala v jednotlivých krajoch úroveR613 ï 1029 EUR, pril om na Slovensku bola 805 EUR. Najniğgiu mzdu dosahuje Preǵovský (613 EUR) samosprávny kraj (Obr. 3, Graf 3). Prí| inou nízkej mzdy je nedostatok pracovných príleǵitostí, vysoká miera nezamestnanosti a nízka miera informovanosti o moǵnostiach samozamestnania. V regiónoch s nízkou mzdou sú Q̆ıdia odkázaný dochádzaŠ za prácou, prípadne prijaŠ pracovný úväzok s minimálnou mzdou. Väl ğna regiónov s podpriemernou mesal nou mzdou má vysoké zastúpenie vidieckeho obyvateQ̆tva, pril om ğát tieto územia nepodporuje, ostávajú bez rozvojových moǵností, ktoré by aspoR! iastoḷ ne pomohli rieg̉Šekonomickú situáciu týchto marginálnych území.

Obr. 3: Priemerná mesa! ná mzda zamestnanca hospodárstva SR v rokoch 2007 ï 2012, kraje

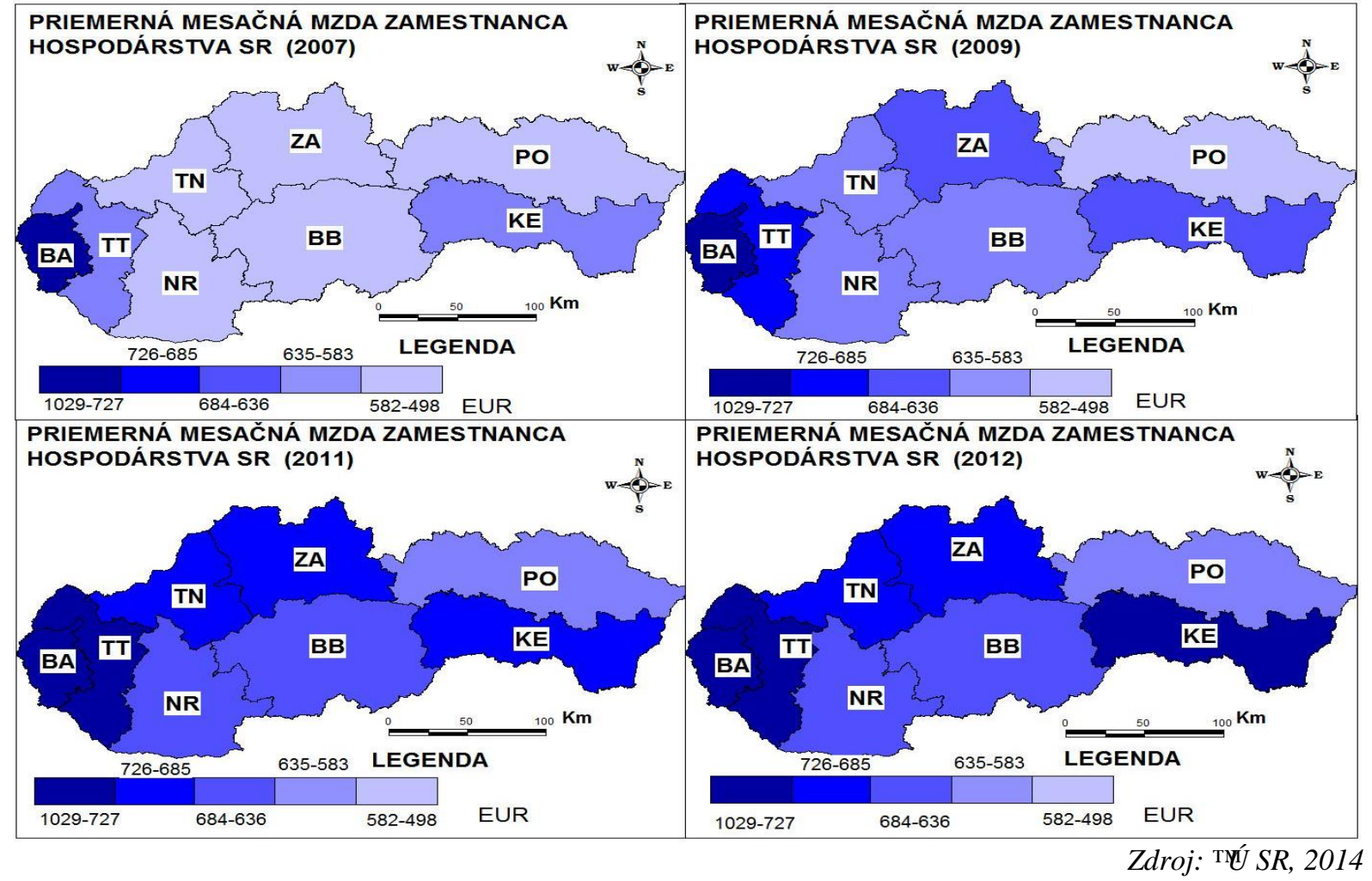


Graf 3: Priemerná nominálna mzda v krajoch SR v rokoch 2007 a 2012

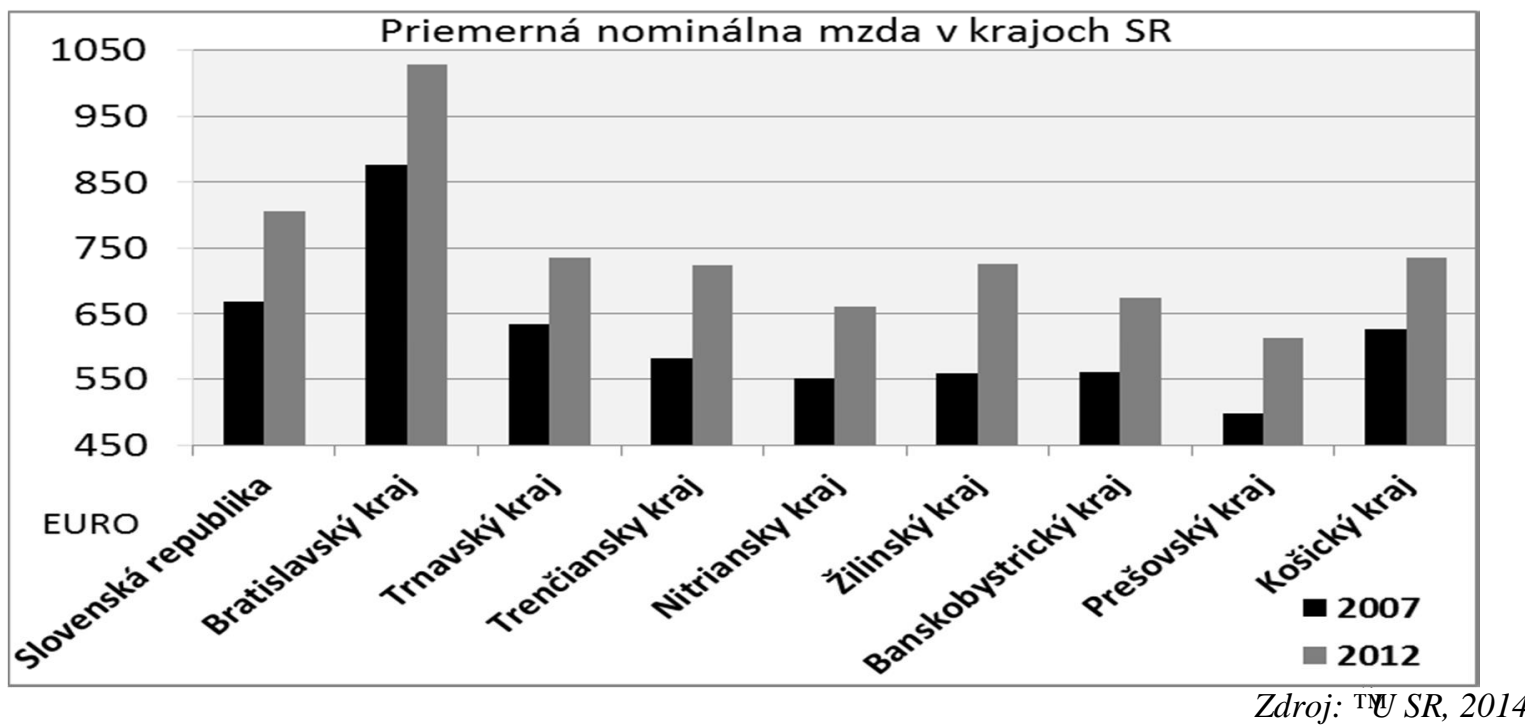

Vzdelanie predstavuje komparatívnu výhody na trhu práce, avğak v súl asnej krízovej ekonomika nie je postal ujúci diplom, ale konkrétna ǵpecializácie, ktorou absolventi dokáǵu presvedḷ iŠ zamestnávateă o svojich kvalitách a nadobudnutých schopnostiach.

Vzdelanostná ğruktúra uchádzal ov o zamestnanie odráǵa nielen koncentráciu vzdelávacích zariadení nadregionálneho a celoǵátneho významu, ale aj hlavné znaky demografickej ğruktúry regiónu, jeho ekonomické postavenie, prosperitu a regionálne osobitosti sociálneho vývoja (Ġvecová, Raj! áková, 2010).

Graf 4: Poḷ et uchádza! ov o zamestnanie v skupine absolventov na 1000 EAO za roky 2007 a 2013 (ă )

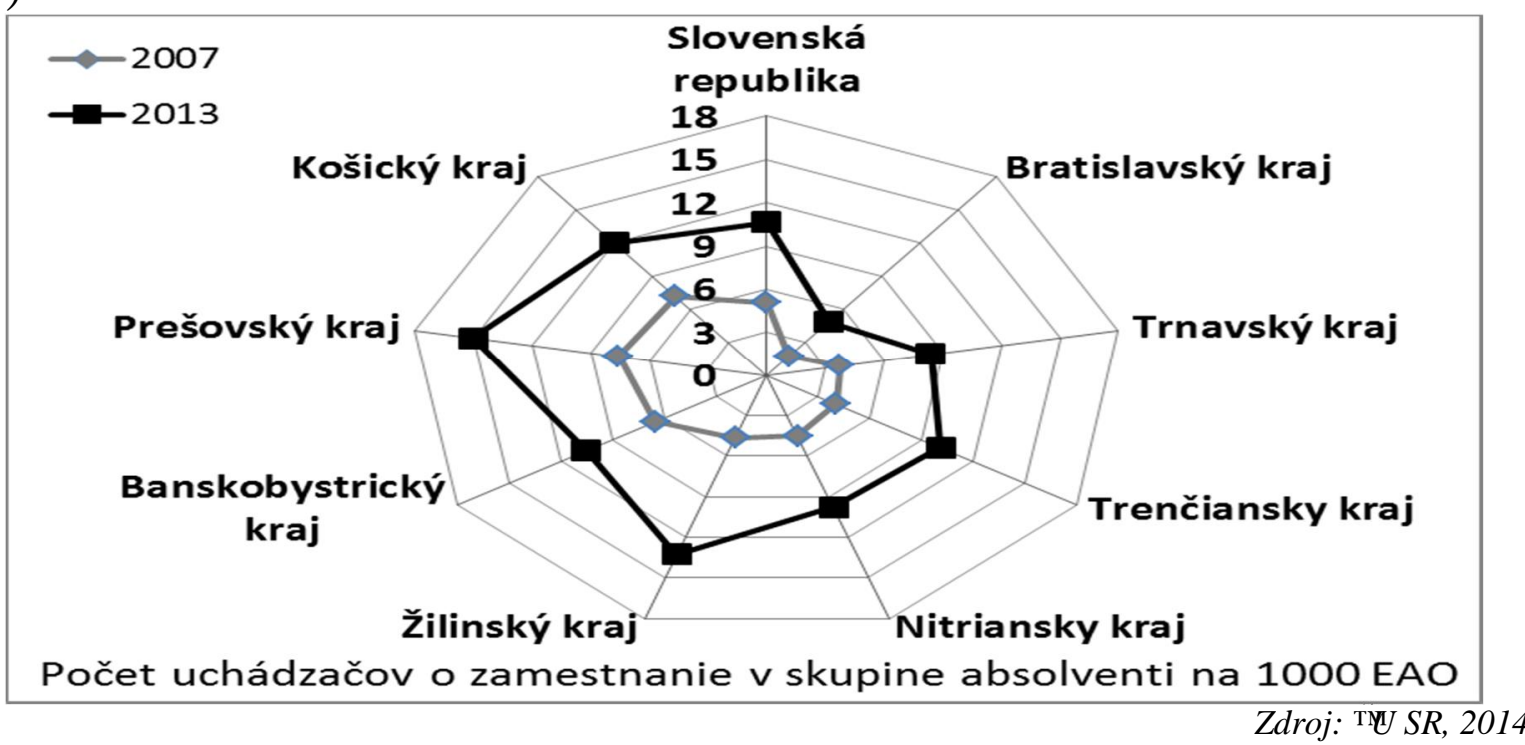

Vývoj poḷ tu uchádzal ov o zamestnanie (absolventov) v jednotlivých krajoch od zal iatku krízy postupne narastal. Najvyğğ poḷ et absolventov bez práce na 1000 ekonomicky aktívnych obyvateØ̆v pripadal v roku 2013 na Preǵovský kraj (15). Pol as celého sledovaného obdobia bol najniğǵ poḷ et uchádzal ov z radov absolventov na 1000 EAO v Bratislavskom kraji. V roku 2007 pripadalo na 1000 ekonomicky aktívnych obyvateØ̆v 1,7 absolventa bez práce, tento trend sa v roku 2013 zvýğil na 4,8 (Graf 4). Ak by sme chceli poukázaŠna príl iny tohto stavu museli by sme pristúpiŠ ku komplexnému hodnoteniu vzniknutej situácie. Slovenská ekonomika v súl asnom krízovom období nedokáǵe absorbovaŠ kaǵdorol ný nárast absolventov vysokých a stredných ġkôl. Viacerí z nich majú 
nedostatol nú a | asto nevhodnú prax, l o bráni pri osvojovaní pracovných návykov. Na druhej strane je potrebné hădaŚ príl iny aktuálneho stavu aj na strane stredných a vysokých ġkôl, keṆǵe ponuka ich programov sa !̣asto vymyká reálnym potrebám a poǵiadavkám zamestnávateQ̆v a trhu práce. Prejavuje sa to najmä v ekonomicky depresívnych regiónoch Preġovského, Banskobystrického a Kog̈ckého kraja.

Posledným ukazovateQ̆m sme chceli priblígíš aktuálny trend vývoja dlhodobej nezamestnanosti $\mathrm{v}$ jednotlivých samosprávnych krajoch na Slovensku. Na tento úl el sme si zvolili ukazovateŎpol tu dlhodobo evidovaných uchádzal ov o zamestnanie prepoḷítaný na 1000 ekonomicky aktívnych obyvateŎov (Obr. 4, Graf 5). Tento podiel je rozdielny vzhădom na ekonomickú výkonnosŠ a vyspelosŠ jednotlivých krajov. V roku 2013 nadobúdal tento ukazovateŎ najniǵğe hodnoty v Bratislavskom (21,7 ă ) a Trnavskom kraji $(38,9$ ă ) na opal nom konci sú depresné kraje ï Preǵovský (131,1 ă ), Banskobystrický (123,9 ă ) a Kog̈ický (117,7 ă ).

Obr. 4: Po!̣ et dlhodobo nezamestnaných osôb na 1000 EAO v rokoch 2007 ï 2013, kraje (ă )

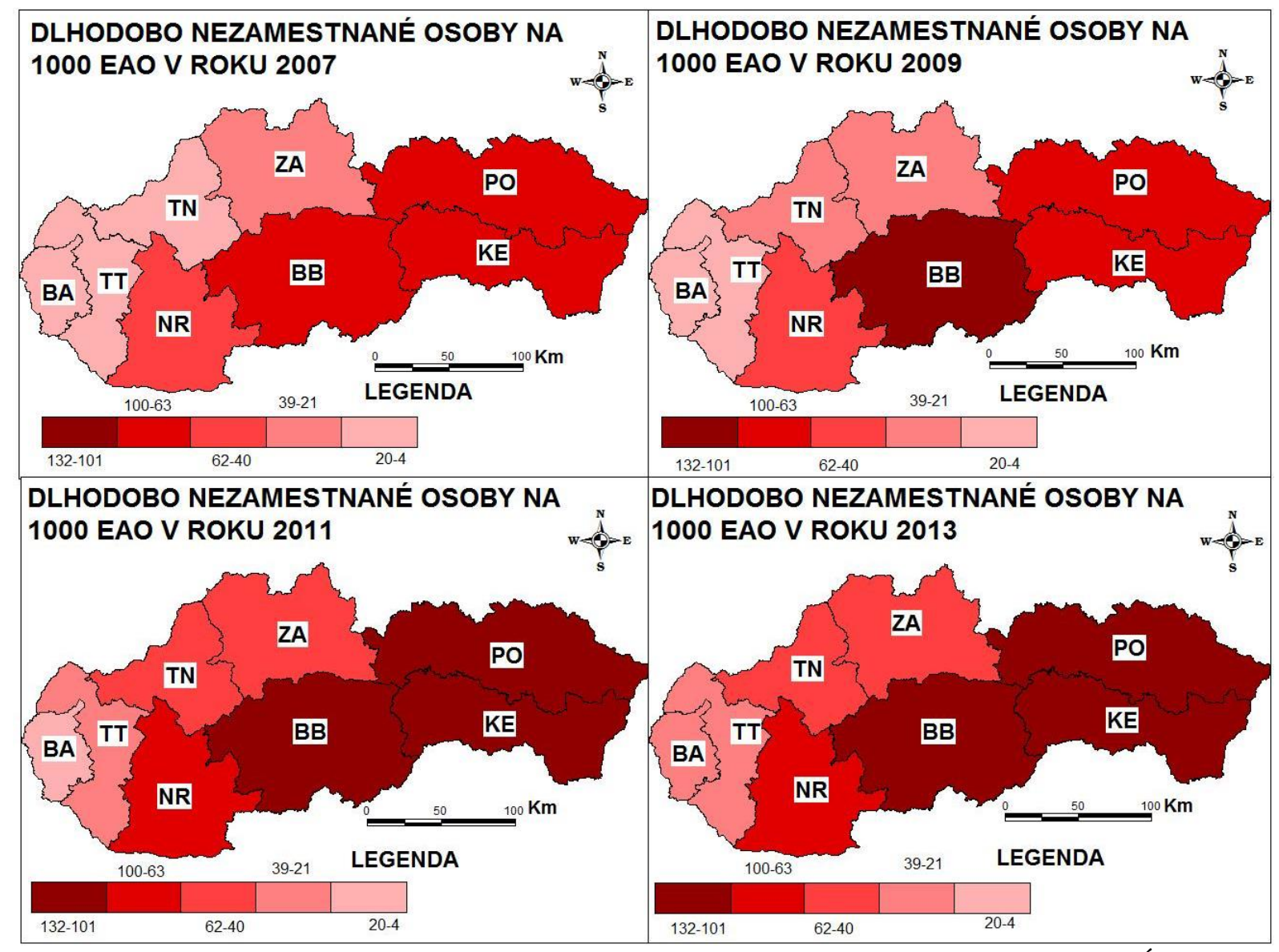

Zdroj: $\dot{\mathrm{G}} \operatorname{SR}, 2014$ 
Graf 5: Po!̣ et dlhodobo evidovaných uchádza!̣ov o zamestnanie na 1000 EAO za roky 2007 a 2013 (ă )

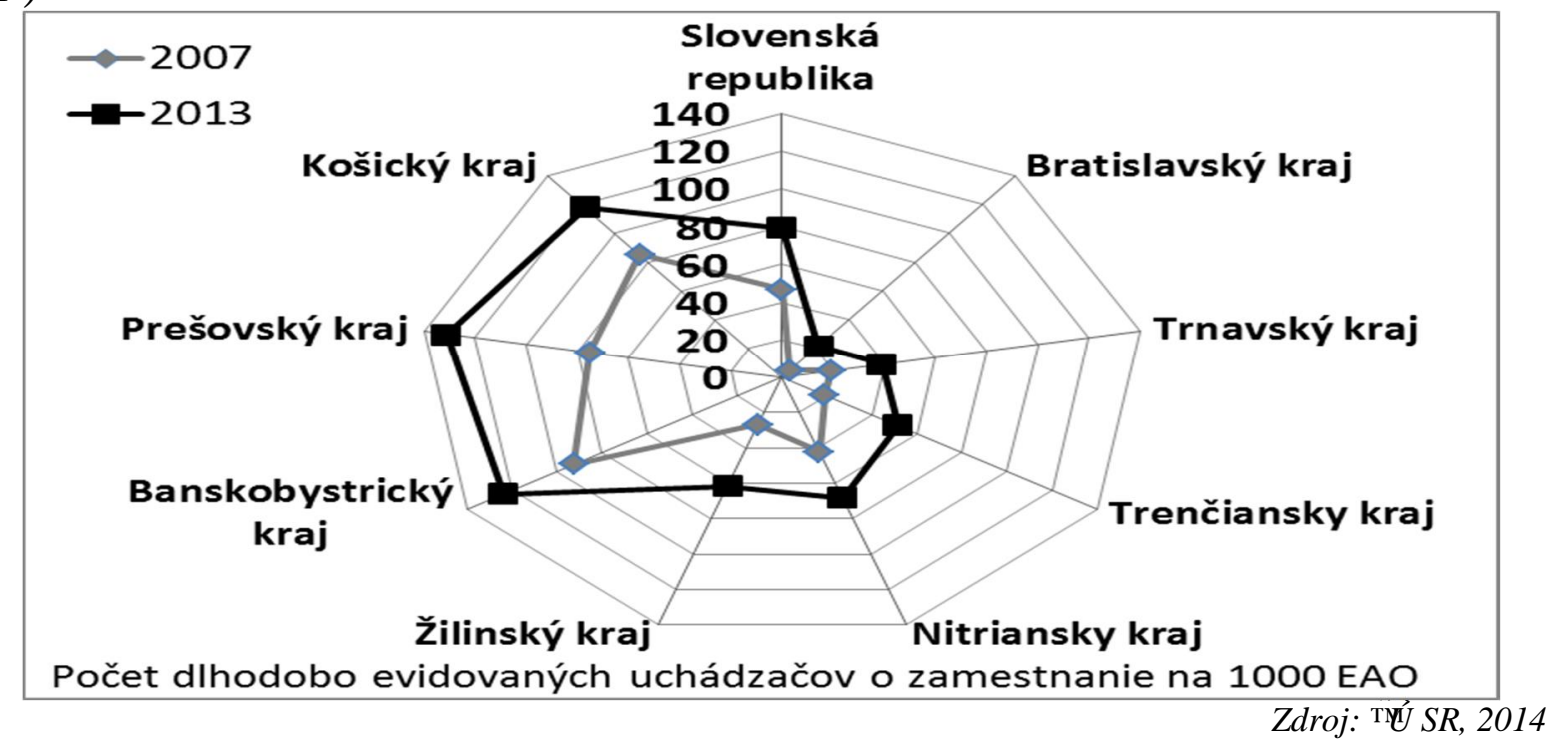

Na potvrdenie predznal ených tendencií sme vyuğili aparát najjednoduchğej bodovej metódy merania socioekonomického rozvoja regiónov (tab. 1), kde posledný riadok znamená celkové poradie jednotlivých krajov na základe priemerných hodnôt jednotlivých ukazovate@̆v. Modrá farba symbolizuje kraje, ktoré dosiahli najlepg̉e hodnoty v rámci socioekonomickej analýzy indikátorov, sivá predstavuje kraje s priemernými hodnotami a l̦ervená reprezentuje kraje, ktoré dosiahli podpriemerné hodnoty analyzovaných socioekonomických indikátorov.

Tab. 1: Výsledky hodnotenia metódou merania regionálneho rozvoja

\begin{tabular}{|l|c|c|c|c|c|c|c|}
\hline Názov kraja & 1 & 2 & 3 & 4 & 5 & Body & Poradie \\
\hline Bratislavský kraj & 4,4 & 4,5 & 969 & 3,8 & 11,7 & 5 & I. \\
\hline Trnavský kraj & 7,5 & 8,5 & 696 & 7,6 & 28,4 & 10 & II. \\
\hline Trenl iansky kraj & 8,7 & 9,3 & 653 & 9,1 & 34,3 & 16 & III. \\
\hline Nitriansky kraj & 11,1 & 12,8 & 624 & 9,1 & 54,3 & 25 & V. \\
\hline Gilinský kraj & 10,1 & 11,3 & 663 & 11,1 & 43,5 & 22 & IV. \\
\hline Banskobystrický kraj & 17,9 & 18,9 & 621 & 10,6 & 111,0 & 36 & VII. \\
\hline Preǵovský kraj & 17,1 & 18,3 & 572 & 13,6 & 103,1 & 37 & VIII. \\
\hline Koğgký kraj & 16,6 & 17,4 & 693 & 11,6 & 102,9 & 28 & VI. \\
\hline
\end{tabular}

Legenda: 1 ï Miera evidovanej nezamestnanosti (priemer 2007 ï 2013), 2 ï Miera evidovanej nezamestnanosti ǵien (priemer 2007 ï 2013), 3 ï Priemerná mesal ná mzda zamestnanca hospodárstva SR, bez podnikateQ̆kých príjmov (priemer 2007 ï 2012), 4 ï Pol et uchádzal ov o zamestnanie z radov absolventov na 1000 ekonomicky aktívnych obyvateQ̆v (priemer 2007 ï 2013), 5 ï Pol et dlhodobo evidovaných uchádzal ov o zamestnanie na 1000 ekonomicky aktívnych obyvateQ̆v (priemer 2007 ï 2013).

Zdroj: vlastný výskum

\section{Záver}

Dôleǵitým a v rámci krajín EÚ veăni sledovaným indikátorom rozvoja regiónov je miera nezamestnanosti. Spolu s mierou nezamestnanosti úzko súvisí aj priemerná mesal ná mzda ako najpreukázanejğ indikátor regionálnych disparít. Pol as sledovaného obdobia môǵeme konġatovaŠ ğe najvyğg̈a nezamestnanosŠ bola v regiónoch s najniğgou priemernou mzdou a to sú Banskobystrický a Preğovský samosprávny kraj. Na druhej strane je vğeobecne známe, ǵe k silným stránkam regionálneho rozvoja Slovenska nepochybne patrí kvalifikovaná a naN̦alej relatívne lacná pracovná sila. Komparatívna výhoda v podobe nízkej mzdy sa prejavila v spojení s realizáciou priamych zahranil ných investícií, ! o súviselo s existujúcou ponukou moǵností pre rozvoj podnikateăkých aktivít v regiónoch ako napr. Trnavskom (PCA Slovakia, s r. o.) a G̣linskom (Kia Motors Slovakia, s r.o.) kraji. Napriek týmto a mnohým iným investíciám Slovensko neúspeg̉ne bojuje 
s nezamestnanos ̌̌ou absolventov a dlhodobou nezamestnanos Šou. Moǵností rieğenia daných problémov je viacero, avğak bez súl innosti aktívnych opatrení regionálnej politiky na centrálnej a regionálnej úrovni (prispôsobenie ġudijných odborov aktuálnej ponuke zamestnávateQ̆v) nemôǵeme oḷ akávaŠzlepġenie danej situácie.

\section{Literatúra}

[1] ANGELOVIL, M., (2009). Regionálne disparity v Srbsku na úrovni okruhov. In Význam đ̆dského potenciálu v regionálnom rozvoji. Podhájska: Východoeurópska agentúra pre rozvoj. pp. 16-23. ISBN 97880-970277-0-4.

[2] ANGELOVIL, M., (2012). Vybrané teoreticko-metodologické aspekty výskumu kvality ǵivota s prihliadnutím na prihranil né regióny. In Folia Geographica 20, vol. 54, iss. 20, pp. 80-96. ISSN 13366157.

[3] HAMPL, M., (2001). Geografie transformace v L̦eské republike: celkové zhodnocení. In Regionální vývoj: specifiká le eské transformace, evropská integrace a obecná teorie. pp. 27-41.

[4] HORKÁ, L., (2013). Factors of socioeconomic development of regions: an alternative approach to an assessment of regions. In 16th International Colloquium on Regional Sciences. Conference Proceedings. Brno: Masarykova univerzita. pp. 51-59. ISBN 978-80-210-6257-3. DOI 10.5817/CZ.MUNI.P210-62572013-5.

[5] HUGGINS, R., (2003). Creating a UK Competitiveness index: Regional and local benchmarking. Regional Studies, vol. 37, iss. 1, p. 89-96. ISSN 1360-0591. DOI 10.1080/0034340022000033420.

[6] KOREC, P., (2003). Population development, urbanization and regional disparities of Slovakia. Acta Uniersitatis Carolinae: Geographica, vol. 38, iss. 1, pp. 167-180.

[7] LUKNIĠ M., (1985). Regionálne !̣ lenenie Slovenskej socialistickej republiky z hădiska jej racionálneho rozvoja. Geografický lasopis, vol. 37, iss. 2-3, pp. 137-163.

[8] MICHAELI, E., MATLOVL,, R., IǴTOK, R., et. al., (2010). Regionálny rozvoj pre geografov. Preg்v: Preg்ovská univerzita v Preg்ve. ISBN 978-80-555-0065-2. p. 717.

[9] Regionálna ġatistika, Trh práce, Evidovaná nezamestnanosŠ GUU SR, 2014 Regdat, 2007-2013, Dostupné z: 〈http://px-web.statistics.sk/PXWebSlovak/>

[10] SKOKAN, K., (2004). Konkurenceschopnost, inovace a klastry v regionálním rozvoji. Ostrava: Repronis. ISBN 80-7329-059-6. p. 160.

[11] ĠECOVÁ, A., RAJḶÁKOVÁ, E., (2010). Regonal disparities of unemployment in Slovakia. In 13th International Colloquium on Regional Sciences. Conference Proceedings. Brno: Masarykova univerzita. pp. 118-125. ISBN 978-80-210-5210-9.

[12] TUROK, I., (2004). Cities, Regions and Competitiveness. Regional Studies, vol. 38, iss. 9, pp. 1069-1083. ISSN 1360-0591. DOI 10.1080/0034340042000292647.

[13] WOKOUN, R., (2010). Teoretické a metodologické pŚstupy k výzkumu regionální konkurenceschopnosti. Regionální studia, 2/2010 pp. 2-7. 